\title{
A Toy Museum in Education: Evaluation of Ankara University Toy Museum's Training Activities
}

\author{
By Müge Artar ${ }^{*}$, Ceren Karadeniz, Hülya Ateş ${ }^{+}$\& Banu Doğan ${ }^{+}$
}

\begin{abstract}
The toy presents a little discovered image of a culture. In addition to being an important object of nostalgia, it is also considered as a research and study subject. The rapidly increasing number of toy museums has also gained importance in transferring economic, sociological, social, and cultural characteristics of the toy. Toy museums have responsibilities such as protecting toys that are threatened with extinction during the rapid change in technology, conducting research on childhood and history of education, raising awareness of history, helping to establish intergenerational communication, and emphasizing the importance of toys in child development. Toy Museums develop educational activities for different ages and interest groups based on their collections. Effective use of collections in museums and the presentation of available resources for visitors with fun, attractive, and different learning methods is one of the characteristics of museum education. Learning from the object, which is one of the basic concepts of museum education, can provide an experience with real objects. The Ankara University Toy Museum can be used as an educational laboratory for courses in preschool, primary, and secondary school education programs within the context of its current collection. The museum can be visited with an appointment with a guide. Search and find activities through collection themes etc. are accompanied by the museum guides and educators. In this study, the evaluation of the design processes of the education booklets of the Toy Museum is determined. The booklets include museum guided tours, and structured educational activities like "before the museum, museum practice, and post museum" activities. Museum booklets have an evaluation section that enables the student to receive feedback where they are expected to make a sustainable contribution to the promotion of the museum. In this context, this paper evaluates the effectiveness of preschool, primary, and secondary school education books that were prepared for the toy museum in line with the feedback of students participating in museum education by establishing a link between the curriculum and the museum collection.
\end{abstract}

Keywords: museum, toy museum, children's culture, museum education, museum booklet

\section{Introduction}

The object is an important part of learning. The context of the object in the museum can be explained by showing both the richness of its collection and the fulfillment of educational functions through the object. Museum education is a field that improves communication and interaction between people and the environment. In the museum education process, museums and galleries are aimed to be an optimal learning environment for people of all ages. It is also acknowledged that museum education is a dynamic and constructive education

\footnotetext{
*Professor, Faculty of Educational Sciences, Ankara University, Turkey.

${ }^{ \pm}$Associate Professor, Faculty of Fine Arts, Ankara University, Turkey.

${ }^{\ddagger}$ Research Assistant, Toy Museum, Ankara University, Turkey.

${ }^{+}$Research Assistant, Toy Museum, Ankara University, Turkey.
} 
that prepares children and young people for the future, and helps people adapt to the changing and developing world. It is inevitable for museums to prepare and implement edutaintment activities for the interests and needs of children, young people, and adults by using museum objects in order to catch the time. Toy museums have aims such as bringing toys, which are a historical, social, and cultural product, to children, young people, and adults, to research the history of childhood, and to use the museum for educational and research purposes. The objects exhibited in the toy museum are suitable for social life, family life, and industrial history suitable for educational purposes, as well as being proper for planning activities that will enable children to develop their senses, imagination, and creativity.

The Ankara University Toy Museum aims to collect, protect, research, transfer children's toys, and play tools to new generations and promote the culture of play and toys with collection-oriented educational activities. Following the establishment of the Ankara University Toy Museum, respectively several samples were established as Musa Baran Toy Museum (1990), İstanbul Toy Museum (2005), İzmir Konak Municipality Ümran Baradan Toy Museum (2010), Antalya Toy and Play Museum (2011), Gaziantep Toy and Play Museum (2013), Samsun Canik Toy Museum (2017), Anadolu Toy Museum (2017), Ankara Çamlıdere Toy and Play Museum (2018) ve Şanlıurfa Toy and Play Museum (2019) in Turkey.

The Ankara University Toy Museum collection is used as a learning laboratory for many courses in preschool, primary, and secondary school curricula. Search and find and "find the themes" activities are accompanied by the other museum education programmes. There have been 20,402 preschool children, 30055 elementary school children, and 13,000 adults who visited the museum for several purposes. Children participating in toy museum educational activities make logical inferences about objects, solve concrete problems, and participate in large and small group discussions instead of looking at the superficial properties of the objects.

The concept of the museum is included in the elementary school curriculum of the Ministry of National Education in detail. In secondary school programs, there are many elective courses especially Social Studies, Science, and Visual Arts, which include activities suitable for the museum consciousness learning area. It is aimed to use informal learning environments such as museums, art galleries, and archaeological sites more effectively for educational purposes in order to reveal students' and teacher's knowledge, skills, and abilities in artistic, cultural, and social fields and to improve their aesthetic tastes with the "museum education protocol" signed between the Ministry of Culture and Tourism and the Ministry of National Education in 2016. In teacher training programs, studies in the field of museum education have been implemented in new programs that came to the agenda in the 1996-1997 academic year simultaneously with the primary education programs. In Preschool Teaching, Social Studies, and Classroom Teaching Programs, elective courses in which pre-service teacher training methods and techniques related to the effective use of museums in education were included in the teacher training programs of Education Faculties. The museum developed educational packages for Primary School $1^{\text {st }}-4^{\text {th }}$ grades and Secondary School $5^{\text {th }}$ 
$8^{\text {th }}$ grades which were based on the museum collection. Museum's educational purposes of the museum are as follows:

1. To create educational books that will provide opportunities for students to learn by doing and experiencing.

2. To collect the activities in social life, family life, social and political history, art, science and social sciences, etc. in a training book for preschool courses, primary school $1^{\text {st }}-4^{\text {th }}$ grades, and secondary school $5^{\text {th }}-$ $8^{\text {th }}$ grades for classroom teachers.

3. To reveal the views of students and teachers regarding the education books for preschool, elementary, and secondary school teachers and students.

This paper evaluates the effectiveness of preschool, primary, and secondary school education books that were prepared for the toy museum in line with the feedback of students participating in museum education by establishing a link between the curriculum and the museum collection.

\section{Methodology}

\section{Research Model}

A screening model is used in this qualitative study in which educational activities of the Ankara University Toy Museum and museum education books were evaluated. Scanning is a research model that describes the relationships, practices, perspectives, beliefs, or attitudes that existed in nature and society in the past or present. The current situation is determined with the documentary scanning model specific to the museum training packages of various toy museums. This is considering the information obtained from the Ankara University Toy Museum museum education books, preschool, primary school 1-4, secondary school 5-8. It has ben prepared in line with the curriculum for classroom teachers and students. The activities in the educational books which were prepared for preschool, primary, and secondary school students and teachers are finalized in line with the feedbacks.

\section{Study Group}

Toy Museums from Turkey and around the world consisted of the study group in the first phase of the study. Toy Museums in Turkey were examined in terms of educational activities. After examining the toy museums in the world with purposeful sampling in terms of accessibility, museums with educational packages were selected. Training books of toy museums are directly related to the collection of Museums. It is also determined that the educational books are prepared in relation to the national education programs of the country and the region in which they are located. In the second phase of the study, semi-structured interviews were 
conducted with three different working groups consisting of preschool, primary, and secondary school students and teachers.

\section{Collecting Data}

The data on the characteristics of the toy museum education packages were obtained via the internet and through correspondence with the museums. Documents, brochures, visual materials, and online publications related to the toy museum educational packages were evaluated.

\section{Data Analysis}

During the data analysis process, the data obtained from the semi-structured interview forms were analyzed by two researchers and systematically entered into the MAXQDA qualitative data analysis program. The research report was prepared based on the data classified and coded using the MAXQDA qualitative data analysis program and the observation forms.

\section{Interpreting the Findings}

\section{Toy, Play and Museum}

The history of the concept of play is dated to ancient times (Sormaz 2012, p. 123). According to Huizinga (2006), play is not the result of coming from various cultures or by coincidence, but it is the main element in the birth of cultural styles. Considering that play has an important appearance in our actions, it would not be wrong to say that we do not do this only with a reaction or instinct, but that there is a transformation from play to culture in its origin (And 2012, p. 27). Play is free where the child temporarily leaves real-life and enters his world in it. The play is also unique, it begins and ends with a specific time and place. It is also continuous and repeated like tradition (And 2012, p. 28). Play is tied to certain abstract or concrete rules system determined by the play itself or the player. The play allows children to gain experience that helps them learn about their world and other people. Play allows the child to research, learn, control, and establish a relationship between what he or she learned (Sormaz 2012, p. 128). Play is on the basis of physical, cognitive, emotional, and social development with or without a specific purpose or rules but it gives optional pleasure in any situation. Play is a symbolic tool that enables the child to express his or her impulses and contradictions between the innate and the environment in physical and cognitive growth (Elkind 2011, p. 68). Children construct their own inner worlds in a play as economic structure, social beliefs and values determine it (Artar et al. 2004).

Play is an essential component of children's culture. The toy is the tool required by the play. The toy is an object that develops the child's imagination, entertains, educates, and teaches him to share (Sormaz 2012, p. 137). With the progress of industrialization and urbanization, the toy created by modern life is 
separated from the traditional toy. Onur (2010, p. 14) states that traditional toys should be named as play material or objects. Since ancient times, one of the main functions of the toy is to prepare people for real life. The toy is also an object of research and examination that reflects the characteristics of the period in which it was produced. The toy constitutes a part of the historical materials that can transfer the economic, social, and cultural characteristics of the period in which it is used from generation to generation. Toys also present undiscovered images of culture and civilization. Therefore, toys must be conserved and restored like other cultural heritage elements.

Considering that museums are institutions that should collect, preserve, promote and research objects and artifacts which are valuable for people, toy museums are expected to fulfill their duty of collecting and conserving toys (Karadeniz 2016, p. 13). According to ICOM, toy museums, which are considered "specialty museums", are the institutions that provide information and education about child and play culture by approaching the social history (Artar and Karadeniz 2017, p. 478). The primary purpose of toy museums is conservation play and toy culture. Besides, toy museums provide opportunities to compare past and present. Onur (2016), states that toys must be protected because they reflect the social and cultural characteristics of the period that they were produced. According to him, toy museums have the same functions as other museums as research and education. In these Museums, both art and cultural history are investigated through toys. The educational function also helps children to establish a relationship between generations by acquiring knowledge of history (Onur 2016). The toy museum is a dynamic museum that monitors the development of toys through the ages, investigates its meaning and function, reveals the social and historical conditions of the era in which it was produced, and interprets the conditions of the age. Meanwhile, it is an educational institution that collects, preserves, exhibits, researches, interprets toys for the cultural and academic wellness of the audience, and uses them for educational purposes.

Onur (2010) lists the toy museums, which are rapidly increasing in number in the world, as the reason for his suggestions to give importance to play and toys. In addition to toy museums in developed countries, the doll museum, toy and model museum, teddy bear museum, museum of play, puppet museum, education museum, school museum, children's museum, children's art museum, children's literature museum, digital game museum, children's science and exploration center and planetarium are increasing (Karadeniz 2010). In addition to being able to respond to an aesthetic taste and emotional need of children, toy museums also have functions such as asking their audience questions and directing them to research (Onur 2010, p. 12). Toy museums do not only compile, but also collect, and preserve nostalgic objects, such as collectors. They use the toy, which is also included in archeology, history, and ethnography museums, for interpretation, exhibitions, and education in different contexts. The purpose of establishing a toy museum is to bring the child and the toy together and to use the museum for education and research (Onur 2010, p. 12).

Toy museums, which conduct research on the history of games and toys, are in the category of museums of interest, unlike children's museums and Museums 
of childhood. Childhood museums are a kind of social history museum that research the history of childhood where all kinds of childhood objects are situated. A children's museum is defined as a nonprofit educational and cultural institution committed to serving the needs and interests of children by providing exhibits and programs that stimulate curiosity and motivate learning (Association of Children's Museum 2020, Karadeniz 2016, p. 23). Children's museums are the best examples of where the basic principles of museum education are applied (Zilcioğlu 2008, p. 12).

Artar and Karadeniz (2017), mention that toy museums are fictionalized as child-friendly and family-friendly learning environments. In Turkey, the number of toy museums are increasing by the endeavor of private persons and legal entities: "It is important to prepare short and long term institutional plans and museum policies in the process of reaching the international standards required by the contemporary museum, and it is significant to share their aims, functions, management style, audience relations policies, and relations clearly, with other institutions of the museum within the scope of these policies (Artar and Karadeniz 2017, p. 489)".

\section{Education in Toy Museums}

Ambrose and Paine (2006, p. 18) emphasize that the museum, which has been adopted as an institution that contributes to the formation and development of an individual's observation, logic, creativity, imagination and taste, has been carrying out activities such as observation, practice, and prediction with contemporary teaching methods and techniques for raising individuals questioning, thinking, and creativity skills since the $21^{\text {st }}$ century. The museum also strives to become an institution that offers a different learning and entertainment experience to its audience.

There have been many kinds of research that museums can be used as effective educational institutions from primary school up to the end of university education. Marcus et al. (2012, pp. 7-8) stated that museums provide rare learning experiences that can increase students' historical knowledge and understanding skills, that they are a source of access to reliable information by interacting with real objects, and that they are sources of information that both affect and are affected by the society through their mutual communication. According to Kaschak (2014, p. 108), the museum benefits, especially in citizenship education processes. Museums play an important role in the construction of national identity with the collections they have, as well as the way they present and interpret these collections (McLean 2007, p. 246, Fladmark 2014, p. 13). Museums also support students' civic attitudes and skills, including social responsibility and civic engagement, as an example of on-site learning in this process. Learning in the museum is "learning from objects". The use of collections, artifacts, and samples is one of the countless ways of learning in the museum. Hooper-Greenhill (1999) states that the object acts like a document; it holds and records the information; and not only does it change as we learn more, it also has a capacity to remind us of what we know. An important feature of learning in the museum is improving 
thinking skills. In this type of learning, it is possible to reach from concrete to abstract, from known to unknown, and from observation to generalization through senses (Onur 2012, p. 48).

Among the UK's leading toy museums, Pollock Toy Museum, Bethnal Green Museum of Childhood, Brighton Toy Museum, and the Museum of Childhood in Edinburgh, Scotland, have detailed museum education books, educational links, and web pages on toys of different themes. The National Museum of Toys and Miniatures in Missouri in the USA organizes daily educational activities for children aged six and over and their families, but the museum does not have an education package. In Germany, thematic studies are carried out using educational packages as well as daily educational activities in examples such as Soltau Toy Museum, Nuremberg Toy Museum, and Freinsheim Historical Toy Museum. The Poissy Toy Museum in France, the Wambrechies Old Toys Museum, and the Toy Museum in Brussels prepare educational packages based on their curricula. Education and theater workshops are prepared at the Tartu Toy Museum in Estonia, and structured trainings are organized based on thematic education sheets. In Japan, Nagoya Spinning Top Museum and Yokohama Tin Toy Museum organize weekends for children and their families and weekdays for students and teachers.

\section{Educational Activities of Ankara University Toy Museum}

The Ankara University Toy Museum has been visited by 75,000 people since its establishment in 1990. The museum works with the mission of "being a childfriendly (family-friendly) museum that focuses on the history of toys and children's culture, offers programs and activities for learning by doing and living, and aims to produce for and with children". In this context, the museum has determined its vision as follows: "Investigation of children's culture with the history of play and toys in Turkey and development of resources required for museumification through contemporary context, and to ensure the sustainability of these resources."

The museum prioritizes audience studies in the process of finding or creating these resources and carries out audience development activities within the scope of museum education. Aiming to use the principles and methods of museum education effectively, the museum's education is planned and implemented under seven headings:

- Guided museum tours and lectures (different age and interest groups).

- Structured (thematic) educational studies at preschool and primary school level.

- Teacher's training activities for Museum Education.

- Training for Museum Education Master of the Arts students.

- Visits of interest groups (adults).

- Working areas for researchers.

- Visits of researchers (conferences, seminars, congress etc.)

- Training for volunteers in a museum. 


\section{- Maker workshops for students and teachers.}

The "museum volunteering" system in museums in Europe and the USA is carried out by museums or non-governmental organizations themselves. It became the most important driving force of museums in the sustainability process. The Toy Museum also hosts voluntary museum education activities initiated by various non-governmental organizations by providing museum training to volunteer museum educator groups on the School - Museum Days. According to Andresen (2002), a museum volunteer is a person who not only likes to visit museums but also likes to share his/her experiences. Although museum volunteering is a common practice, it is not implemented in a systematic manner in Turkey. Therefore, implementing volunteering as a sustainable strategy in museums will set an example for many cultural institutions that have staff shortages.

The most popular museum educational activity is the maker workshop for students and teachers. The maker movement is a cultural trend that places value on an individual's ability to be a creator of things as well as a consumer of things. In this culture, individuals who create things are called "makers". Makers come from all walks of life, with diverse skill sets and interests. The thing they have in common is creativity, an interest in design as well as access to tools and raw materials that make production possible (Rouse 2014). The Maker Movement consists of the combination of technology and the "do it yourself" culture that has spread rapidly in the last decade. Maker is prepared with contents such as model aircraft making, electronic circuit design, printing or producing various items with 3D printers, jewelry design, and toy making, depending on the activity it is linked to. According to the constructivist approach, which emphasizes that past experiences are important for the individual to make sense of new information, a person can understand new information by integrating her previous knowledge and adding meaning according to herself (Slavin 2014, p. 219). There are many studies investigating how maker experiences in museums shape children's thinking and learning styles (Brahms 2014, Gutwill et al. 2015). These researches are generally descriptive and ethnographic studies conducted by professionals working in various museums and science centers (Bevan et al. 2015).

According to Brahms and Crowley (2017), maker activities are among the most important workshops of out-of-school learning environments. In the first phase of the Ankara University Toy Museum maker event, museum education studies were carried out on the past and future of the toys in the museum, and then children were allowed to design their own toys with the Tinkercad program (Figure 1). They freely designed the toys that they liked and whose history attracted their attention among the toys they saw in the museum, in the same program. During the process, inspired by the museum work, toys such as a washing machine, a double-decker bus, a piggy bank, a robot, a mug cup, a tower, a car, a house, a sword, a castle, an alien, as well as a snowman were designed. 
Figure 1. Maker Activity in the Museum, Toy Design and Virtual Museum Tour

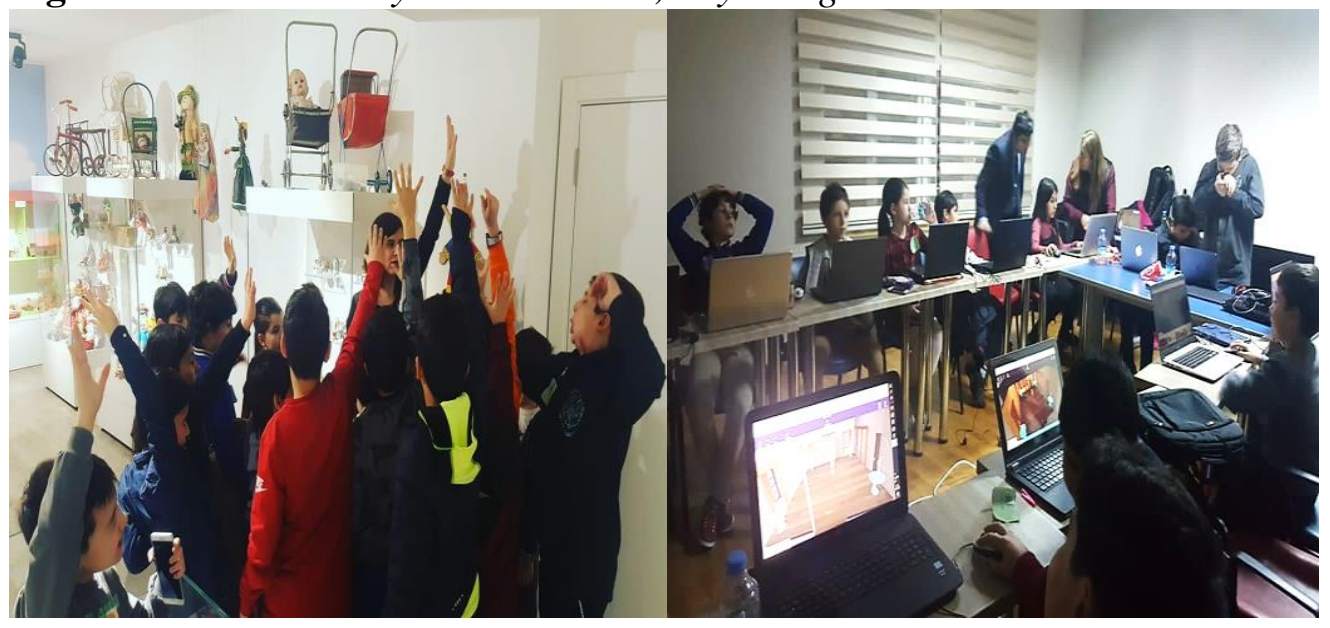

The Ankara University Toy Museum collection exhibition themes are Vehicles/Transportation, Intelligence Games, Music and Entertainment Culture, School Culture, Construction, Home Sweet Home, Babies, Animals, Doll House Set, Street Games, Trains, Tin Toy Collection, Foreign Traditional Dolls, Spacecrafts, Race Cars, Trinkets, Porcelain and Knitted Dolls, Garden and Beach Toys, Stuffed Toys, Objects of Childhood and Cradles. The museum needed an education package in order to provide an enjoyable environment where pre-school and primary school students who visit the museum can increase their skills and capacities, enable them to learn by doing and experiencing, as well as communicating and interacting with their peers. This educational package was prepared for pre-school age groups and primary school $1^{\text {st }}$ to $4^{\text {th }}$ grades by examining national curricula and education programs. Preschool education activities are planned according to museum themes, taking into account the characteristics of cognitive development, language development, social-emotional development, and motor development in the curriculum. In the National curricula in primary education of $1^{\text {st }}$ and $4^{\text {th }}$ grades, Introduction to Science, Turkish, Mathematics, Geometry, Music, Visual Arts, Art Activities are basic courses. The elective courses in the classroom such as Chess, Physical Education, Sports Activities, Human Rights, Citizenship and Democracy, Play and Physical Activities, and Creative Thinking courses are included. In the third year, Science Course was added to these courses. In the $4^{\text {th }}$ grade, Social Studies was included. In the National curricula, $5^{\text {th }}$ grade includes Visual Arts, Math, Science, Social Sciences, Turkish, Art Activities. The contents of these courses are relevant to be conducted in a museum. Activities in museum Education packages are related to 5th grade Social Studies and Visual Arts; $6^{\text {th }}$ grade Social Studies and Art Activities; $7^{\text {th }}$ grade Social Studies, Technology Design. These lessons are directly related to the concepts and acquisitions of the units that will overlap with the Toy Museum themes.

Especially $5^{\text {th }}-8^{\text {th }}$ grade students are in progress to adulthood. The participation of this age group in museum activities is important in terms of development issues. In adolescence, there are significant changes in the capacity of the individual to be close with their peers. In adolescence, friendships based on clarity, honesty, 
loyalty, and mutual trust emerge rather than simply sharing activities and interests (Steinberg 2013, p. 27). Most important decisions with long-term consequences on school and career issues are made in adolescence. Many of these decisions are based on adolescents' evaluations of their school achievements, their own competencies and capacities, their expectations for the future, and the guidance and suggestions they receive from their parents, teachers, and friends (Steinberg 2013, p. 28).

\section{Findings and Interpretation}

Ankara University Toy Museum has prepared an educational book that will guide preschool teachers in the museum education field in order to implement contemporary museology approaches based on the educational functions of museums. The significance of informal learning environments with the new primary education program and the adoption of learning by doing approaches make the museum an important learning area. The activities prepared in connection with the units in the teaching programs are important in terms of experiencing the toy as an original object. The book contains activities covering how to apply museum education methods, techniques, and activities in the Toy Museum within the Preschool Education Program and the basic skills and concepts that children will participate in education with these activities.

The Preschool Education Book includes the definition of museum education, explanations about the methods and techniques used in museum education, examples of activities, written-visual materials to be used in activities, and evaluation processes. The book is designed to accompany the cartoon character from the Toy Museum collection to guide students (Figures 2 and 3). Education Books also Include a Toy Map of Turkey (Figure 4).

Figure 2. Stuffed Donkey from Museum Collection to Cartoon Museum Guide
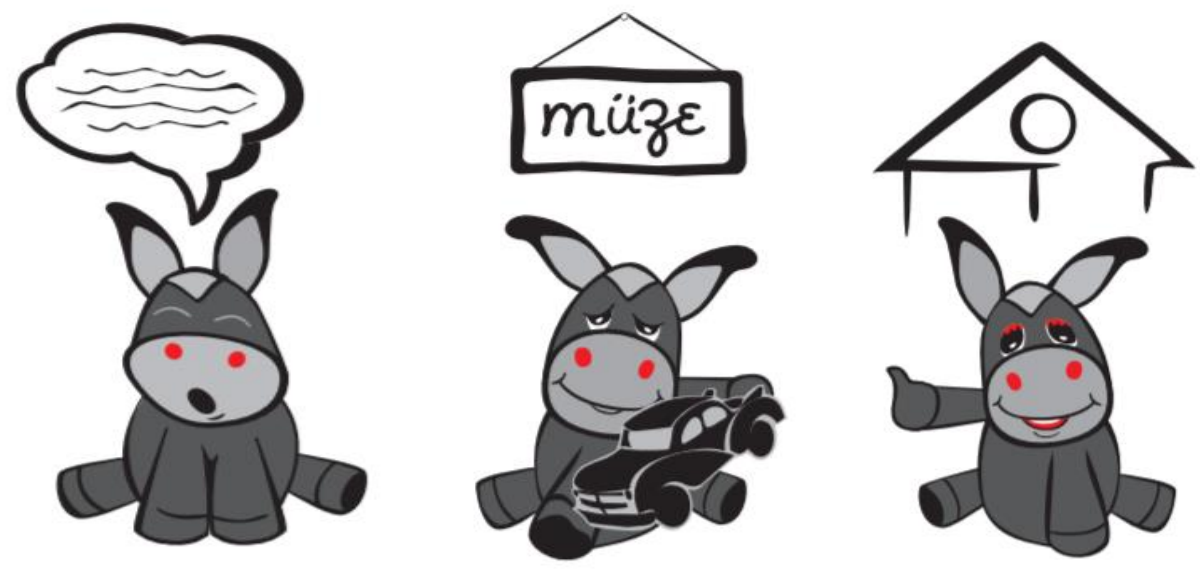
Figure 3. Stuffed Donkey, 1970s Made in Turkey, Brand Fatoş

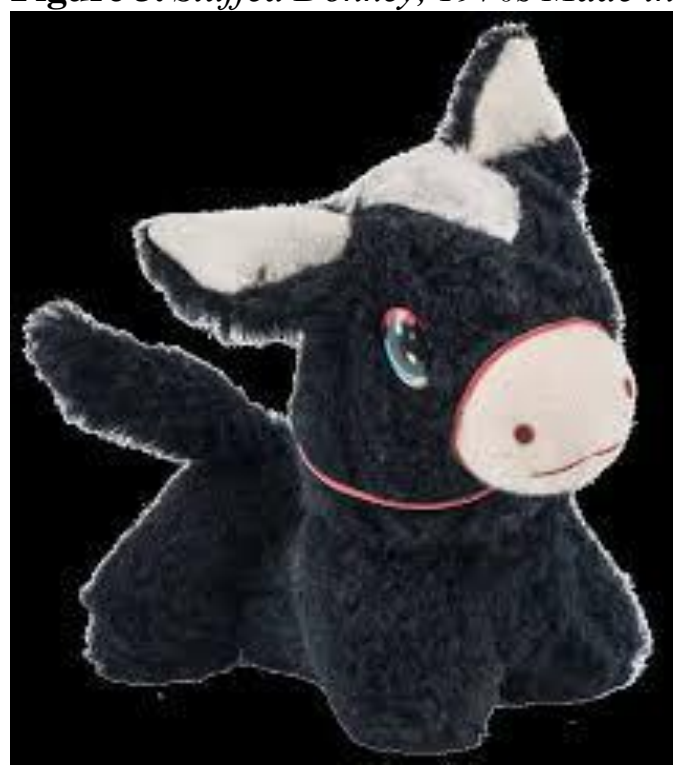

The list of events in the book is presented below:

1. Find the vehicle (Theme: Vehicles/Transportation)

2. Where is the camel? (Theme: Animals)

3. Touch and match (Theme: Play and intelligence)

4. Toys before you - Toys after you? (Theme: Vehicles/Transportation)

5. Once upon a time in a museum (Theme: Vehicles/Transportation)

6. My toy (Theme: Vehicles/Transportation)

Figure 4. Toy Map of Turkey

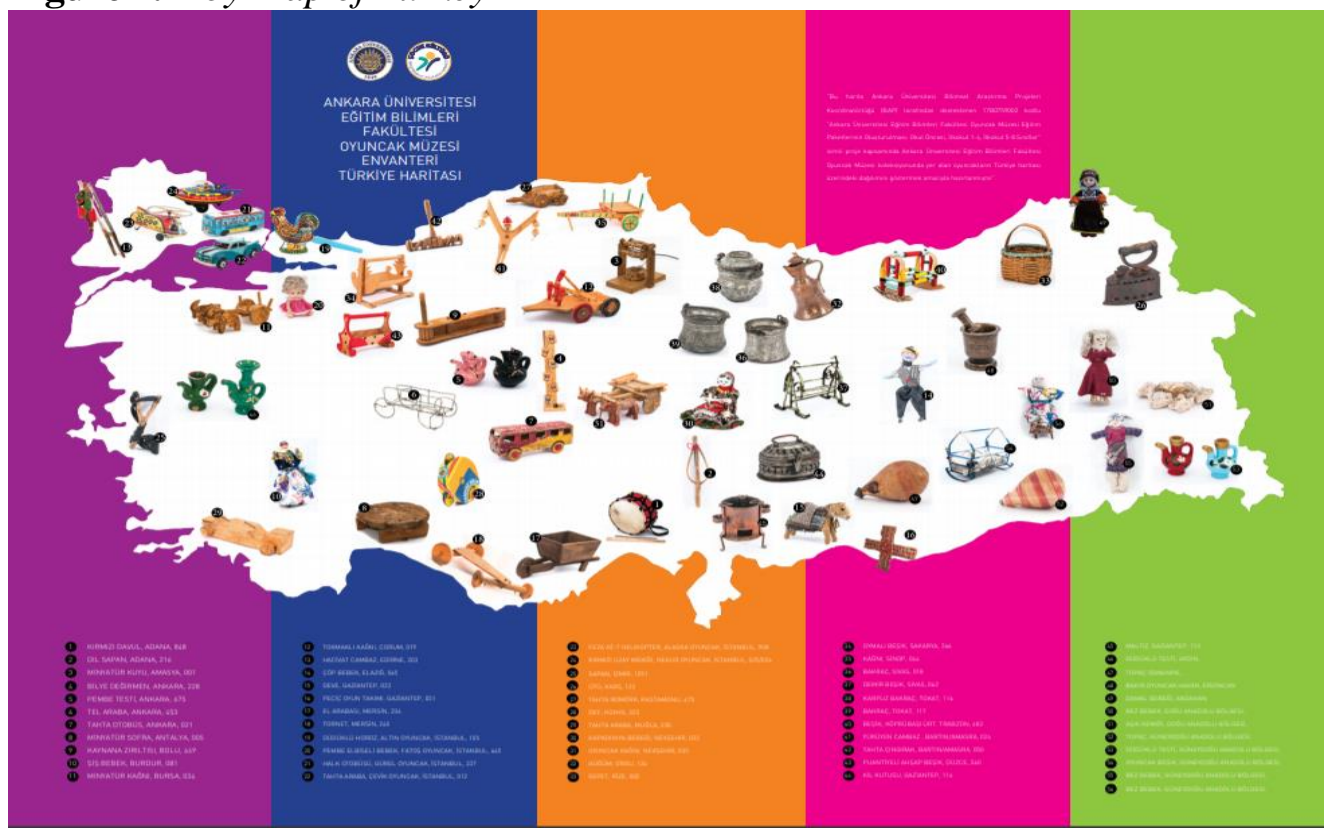


The activities in the Preschool Education Book were implemented with 200 students and the activities were finalized in line with the feedback received by the students (Figure 5). In the context of the activities developed, the following questions were asked to the participants:

1. How much fun did you have at the Toy Museum?

2. Which toy did you like the most during the event at the Toy Museum?

The question "How much fun did you have at the Toy Museum?" was asked in the preschool Education book. Since the students were illiterate, three visual expressions were used and they were asked to paint the expression representing their feelings. It is stated that $94.5 \%$ of the students left the museum activity happily. The questions "Which toy did you like the most during the event in the Toy Museum?" and "Can you draw" were also asked to students. $40 \%$ of the students answered the dolls, 35\% said the vehicles, and 30\% emphasized the dollhouse sets.

Figure 5. Warm-Up Studies at Pre-Museum Process

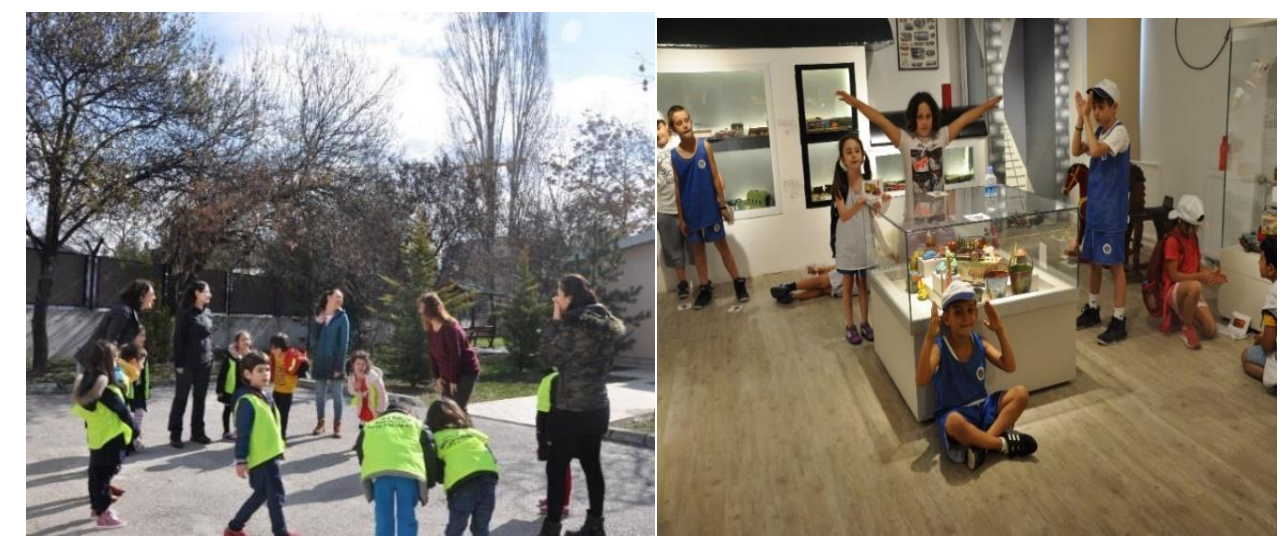

The Primary School Museum Education Book, prepared in conjunction with the units in the curriculum, includes how the education will be implemented within the elementary education program in the museum and the basic skills and concepts that are desired to be acquired by children who will participate in education with these activities.

In the Primary School Education Book pages, there is a description of museum education, explanations about the methods and techniques used in museum education, examples of activities, written-visual materials to be used in activities, and evaluation processes. In the Primary School Museum Education Book, the museum collection has been examined in a way that is integrated with the vision and mission of the Toy Museum, and in line with the Primary School Curriculum, the activities have been prepared to cover the pre-museum, museum and post-museum processes for $1^{\text {st }}, 2^{\text {nd }}, 3^{\text {rd }}$ and $4^{\text {th }}$ grades.

The list of events in the book is presented below: 
1. Home Sweet Home (Unit - My Family and Home - Introduction to Science Course)

2. Toy Collection (Unit - Museum Culture - Art Activities Course)

3. Past-Present-Future (Unit - I Love My Country - Introduction to Science Course)

4. Prizms (Unit - Geometry and Shapes- Math Course/ Geometry Course)

5. Toy Museum (Unit - Feelings in the Museum - Art Activities Course)

6. New Words in Toy Museum (Unit - Word Presence - Turkish Course)

7. Technology and Toy (Unit - Good Thing There is - Social Sciences Course)

8. Find the objects (Unit - Cultural Heritage - Social Sciences Course)

9. Movement of Toys (Unit - Movement od Cultural Assets-Science Courses)

10.Determine the Ribbon (Unit -Time Measuring - Math Course)

The activities in the primary school package were implemented with 200 students and they were finalized in line with the feedback received from the students (Figures 6 and 7). In the context of the activities developed, the following questions were asked to the participants regarding these activities:

1. What are your feelings about the event held at the Toy Museum?

2. Which toy did you like the most at the event you attended at the Toy Museum?

3. Would you like to attend the event you did at the Toy Museum again?

4. What score would you give the Toy Museum and the event?

$45.5 \%$ of the students participating in the event stated that they were happy with it. $11.5 \%$ of them stated that they liked the activity very much, and $10.5 \%$ found it very enjoyable. $20 \%$ of the students emphasized that the toy museum is a very nice place depending on the activity. $5 \%$ of them stated that they were excited about the museum activity; $3 \%$ stated that they found the activity instructive. 3 percent of the students stated that they found the museum too tiny and therefore were disappointed.

The expressions about the question "What are your feelings about the event held at the Toy Museum?" are selected from the student responses to the question. They are presented below:

I have learned how children played in the past. (E.K.9 years)

I am really surprised because everything is handmade. (M.K.9 years)

Come here please, it reminds the past. (E.T.10 years)

I'd like to come if the exhibition changes. (E.Ş.10 years)

I did not want to leave here. (A.A.10 years)

When I said everything was ok at the museum, I encountered new surprises (I.B.A.9 years)

There was no other floor at th museum but I really liked it. (Y.N.K. 9 years)

The museum is tiny but the garden is excellent. (A.S.9 years) 
$34 \%$ of the students liked the home sets the most during the activities. With this percentage, home sets have become the most popular toy group in the museum. Cars follow the home sets with $30 \%$. $20 \%$ of the students stated that they liked construction toys. $17 \%$ stated that they liked dolls and $15 \%$ liked the trains. While 10 percent of the students stated that they liked all the toys in the museum, it was determined that the least liked toy were the oxen with a rate of $2 \% .90 \%$ of the students stated that they would like to participate in the activity at the museum again. As the students saw very interesting things; They stated that they wanted to participate in the activities again because they wanted their parents to see them, and they learned a lot in the museum.

The expressions about the question "Would you like to attend the event you attended at the museum again?" are selected from the responses to the question. They are presented below:

I'd like to come again because I have seen interesting things. (A.K. 8 years)

No, I don't want to come here again because it is very tiny. (A.Ç.8 years)

I'd like to bring my parents here because they should see the museum.

(H.D.Y. 8 years)

I'd like to come here again because I learned a lot. (S.Ü.9 years)

I liked guiding here. (K.E.9 years)

No, I do not want to come here because I want to be famous. (A.B.B. 9 years)

I will come here again because I want that place to be famous. (I.B.A, 9 years)

Figure 6. Educational Activities in the Museum Gallery

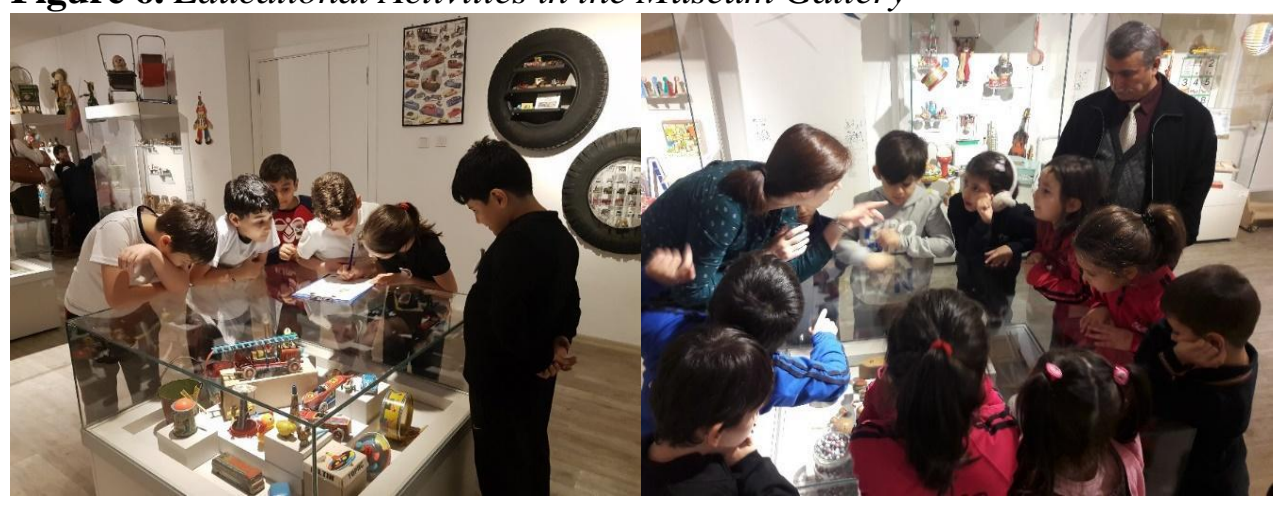

The activities in the educational book developed for the secondary school were implemented with 45 students and the activities were finalized in line with the feedback received from the students. In the context of the activities developed, the following questions were asked to the participants:

1. What are your feelings about the event held at the Toy Museum?

2. What did you learn during the event at the Toy Museum? 
$53 \%$ of the students found the activity enjoyable. According to $24 \%$ of them, the event was informative. While $11 \%$ stated that the event was remarkable, 6 percent stated that this activity made them emotional.

It was like a store selling old toys, injecting peace, and fun into the human body. (Ö.1.12 years)

I like the decoration. (Ö.2.12 years)

Of all the museums I visited, this was the one where I had the most fun. (Ö.3.12 years)

The forgetting of old toys made me sad. (Ö.5.12 years)

Old toys were replaced by new things and the old ones were forgotten. (Ö.6.years)

$29 \%$ of the students stated that they learned that the toys produced in the past were more valuable than today's toys. $22 \%$ stated that they learned the types of toys and $17 \%$ stated that they learned how to use them. $15 \%$ of them also stated that they learned the history of toys through activities.

We have seen that the toys of the past are more valuable and based on handmade tradition. (S.1.12 yass)

I learned how the toys of the past have changed today. (S.2.12 years old)

We have seen different toy types. (S.5.12 years)

My memories are refreshed. (S.6.12 years)

It was interesting to learn about the history of toys. (S.7.9 years old)

I learned that toys are produced from different materials. (S.8.10 years old)

Figure 7. Secondary School Educational Activities in the Museum Gallery

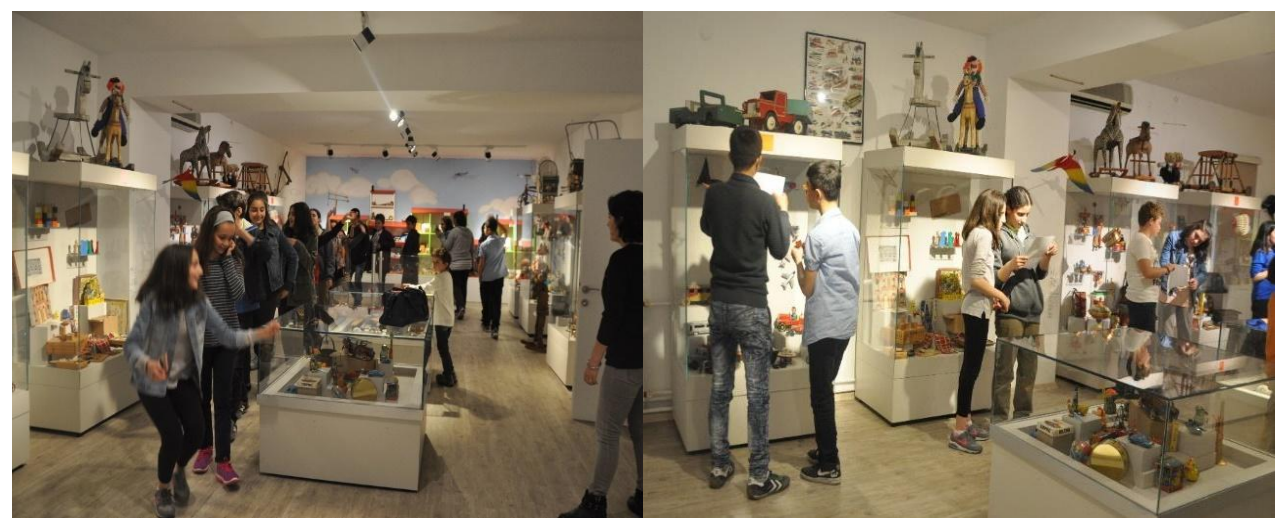




\section{Conclusion}

The primary aim of toy museums is conservation play and toy culture. Besides this function, museums are also lifelong educational institutions and they should play a new role in the transfer of historical processes. To fulfill this requirement, some of them are specially designed for children as children's Museums, Museums of childhood, and toy Museums. When the toy is exhibited in the museums, it gives information about both child culture and social and cultural process of the present age and it helps to improve children's learning skills through themed educational activities which are depended on the national curricula.

Although the functionalist and contemporary toy museums are established in Turkey and various training activities are held there, none of them have a training package designed for use by teachers and students. However, it is among the strategies of contemporary toy museums to use the toy as an educational tool not only as an object of nostalgia but as an indicator of social life, technology, and even economic developments. Although these strategies are not implemented in all toy museums, today it is known that many of them include education, participation and promotion activities, and develop learning materials. Therefore, the Ankara University Toy Museum is also in an effort to develop a training package based on similar contemporary museum strategies. Therefore, as the third step of the research, the lectures in the education program are prepared by the Ministry of National Education Board. That's why a museum education package has been prepared to ensure effective use of the museum for primary school students from 1 st to $4^{\text {th }}$ grades, for secondary school students from $5^{\text {th }}$ to $8^{\text {th }}$ grades, and for their teachers. The package has been prepared to ensure effective use of the museum and has been developed based on the collection of the Ankara University Toy Museum.

In the museum, there are nearly 3,000 toys consisting of approximately thirty themes such as school culture, street games and spacecrafts. The richness of the collection provides the opportunity to develop museum education activities that can appeal to people and subjects from many different fields.

With this training package, it was tried to create a guide on how teachers can use the Toy Museum for educational purposes. This study is a source for other toy museums in Turkey. Researchers and teachers can create a different number of museum education activities suitable for each lesson and unit based on the themes in the museum. Other toy museums take the education packages prepared in this research as an example; they can prepare similar museum education packages for families, children of different age groups, disabled groups, elder people, and disadvantaged groups that can be used by museum educators and teachers.

Based on this determination, the following recommendations have been developed for teachers, Museums educators and museum staff:

1) This package is a sample for preschool, primary school, and secondary school teachers, museum educators and so on. It is a sample of how students can use the museum as an educational environment with a contemporary understanding of museology. 
2) This package can be applied to elective museum education undergraduate courses in different departments.

3) The Ankara University Toy Museum can reach children who cannot reach the museum, who are outside the borders of Ankara, with museum activities, promotional information, and museum loan boxes.

4) Visitors who cannot reach the museum can access the museum via the website with the virtual museum application.

5) The number of visitors can be increased by promoting the museum on social media (Figure 8).

6) The relevant package can be shared with the Ministry of National Education and introduced to teachers within the scope of in-service training.

Figure 8. Museum Education Books are Shared on the Website of the Ankara University Toy Museum
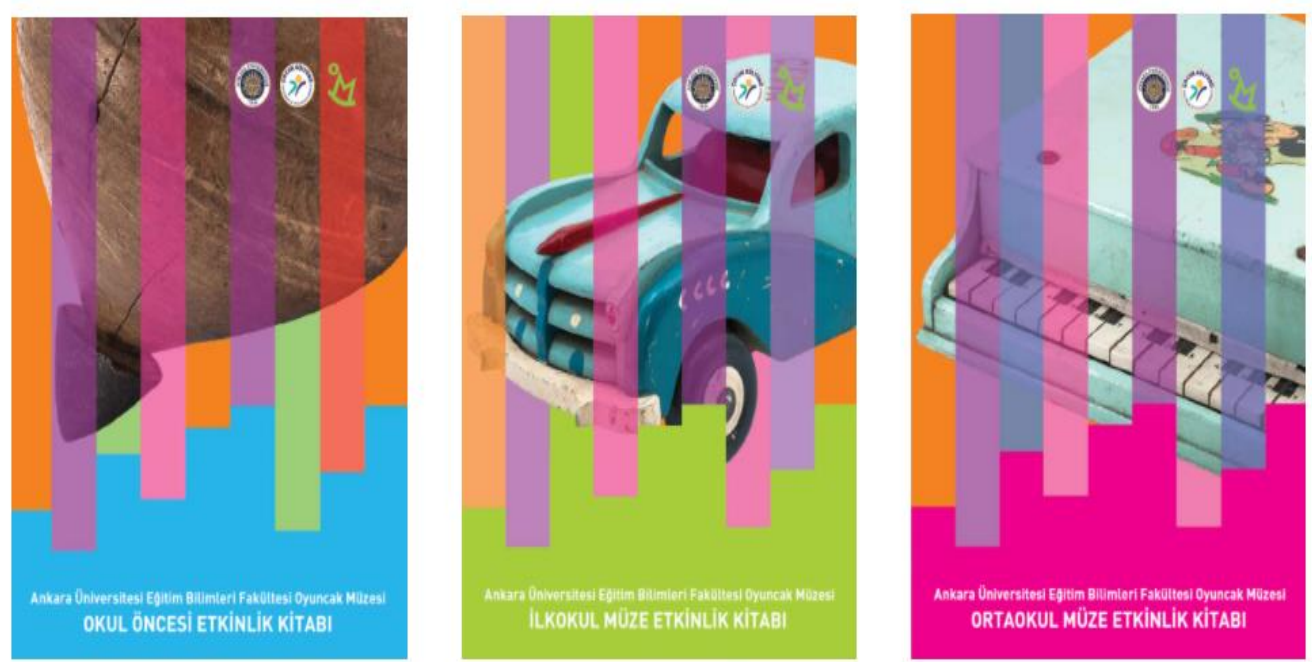

Source: http://cokaum.ankara.edu.tr/oyuncak-muzesi.

\section{References}

And M (2012) Oyun ve bügü. (Play and mind). $3^{\text {rd }}$ Edition. İstanbul: Yap1 Kredi Yayınları. Ambrose T, Paine C (2006) Museum basics. UK: Routledge.

Andresen M (2002) The social role of friends of museums. ICOM News 55(4): 1-16.

Artar M, Onur B, Çelen N (2004) Çocuk oyunlarında üç kuşakta görülen değişimler: kırsal kesimde bir araştırma (Changes seen in generations in children's play: a study in the rural area). In Araştırmalar, B Onur, N Güney (eds.), Türkiye'de Çocuk Oyunları, 151-158. Ankara: Kök Yayıncılık.

Artar M, Karadeniz C (2017) Status and the sustainability of toy museums in Turkey. Electronic Journal of Social Sciences 16(61): 477-492.

Association of Children's Museums (2020) Retrieved from: https://www.childrensmuse ums.org/.

Bevan B, Gutwill JP, Petrich M, Wilkinson K (2015) Learning through stem-rich tinkering: findings from a jointly negotiated research project taken up in practice. Science Education 99(1): 98-120. 
Brahms LJ (2014) Making as a learning process: identifying and supporting family learning in informal settings. Doctoral Dissertation. Pittsburgh, USA: University of Pittsburgh.

Brahms L, Crowley K (2017) Learning to make in the museum: the role of maker educators. In K Pepler, E Halverson, Y Kafai (eds), Makeology in K-12, Higher, and Informal Education: The Maker Movement and the Future of Learning. Routledge.

Elkind D (2011) Oyunun gücü. (The power of play). Edited by B Onur. Translated by D Öngen. Ankara: İmge Yayınevi.

Fladmark MJ (2014) Heritage \& museums: shaping national identity. USA: Routledge.

Gutwill JP, Hido N, Sindorf L (2015) Research to practice: observing learning in tinkering activities. Curator: The Museum Journal 58(2): 151-168.

Hooper-Greenhill E (1999) Müze ve galeri eğitimi. (Museum and gallery education). Edited by B Onur. MÖ Evren, EG Kapçı (çev.), Ankara: Ankara Üniversitesi Çocuk Kültürü Araştırma ve Uygulama Merkez Yayınları.

Huizinga J (2006) Homo ludens. Edited by EI Bask1. İstanbul: Ayrıntı Yayınları.

Karadeniz C (2010) Dünyada çocuk müzeleri ve bilim merkezleri. (Science and technology museums in the world). Edited by B Onur. Ankara: Ürün Yayınları.

Karadeniz C (2016) Türkiye'de oyuncak müzeleri: oyuncak müzelerinin dünü, bugünü ve sürdürülebilirliği. (The past, present and the sustainability of children's museums). Edited by C Karadeniz, B Onur, içinde. Ankara: Ankara Üniversitesi Basımevi.

Kaschak J (2014) Museum visits in social studies: the role of a methods course. Social Studies Research and Practice 9(1): 107-118.

Marcus AS, Stoddard JD, Woodward WW (2012) Teaching history with museums: strategies for K-12 social studies. ${ }^{\text {st }}$ Edition. UK: Routledge.

McLean F (2007) Museums and the construction of national identity: a review. International Journal of Heritage Studies 3(4): 244-252.

Onur B (2010) Oyuncaklı dünya. (World with toys). Genişletilmiş 3. Baskı. Ankara: İmge Kitabevi Yayınları.

Onur B (2012) Çağdaş müze, eğitim ve gelişim - Müze psikolojisine giriş. (Contemporary museum: education and development: introduction to museum pscyhology). Ankara: İmge Kitabevi Yayınları.

Onur B (2016) Ankara üniversitesi oyuncak müzesi: bir müzenin öyküsü. (Ankara toy museum catalogue). Ankara: Ankara Üniversitesi Basımevi.

Rouse M (2014) Maker movement. Teach Target Network. Retrieved from: https://searc herp.techtarget.com/definition/maker-movement. [Accessed 8 December 2020]

Slavin RE (2014) Eğitim psikolojisi kuram ve uygulama. (Educational pscyhology theory and practice. Ttranslated by G Yüksel. Ankara: Nobel Yayın Dağıtım.

Sormaz F (2012) Çocukluk, oyun ve oyuncak: sosyo-kültürel bir analiz. (Childhood, play and toy: a socio-cultural analysis). İstanbul: İkinci Adam Yayınları.

Steinberg L (2013) Ergenlik. (Adolescence). Edited by F Çok. 2. Baskı, Ankara: İmge Kitabevi Yayınları.

Zilcioğlu Ş (2008) Çocuk müzeleri ve müze eğitimi. (Children's museums and museum education). Edited by B Onur. Ankara: Ürün Yayınları. 